\title{
Gerakan Filantropi Islam di Amerika
}

\author{
Fuad Hasyim \\ Universitas Islam Indonesia
}

fuad.hasyim@uii.ac.id

\begin{abstract}
Abstrak
This research aims to explore the development of Islamic Philanthropy movement in America covering the discussion on the institutional basis of Islamic Philanthropy, and its contributions toward the solidarity and the empowerment of muslim community. The research is a kind of literary research with the qualitative research method and multidisciplinary approach. The result shows that there are four institutional basis of Islamic Philantrophy in America; those are mosques, educational institutions, ethnic, and religious school of thought. The facts are also found that there is significant correlation between the existence of islamic philanthropy institution and government political policies on radicalism issues that adhered to muslim community in America.
\end{abstract}

Keywords: America, Philantrophy, Islam, Muslim

\begin{abstract}
Abstrak
Penelitian bertujuan untuk mengetahui perkembangan gerakan filantropi Islam di Amerika yang meliputi pembahasan tentang basis kelembagaan filantropi Islam dan kontribusinya terhadap solidaritas dan pemberdayaan umat Islam di Amerika. Penelitian ini adalah kajian literatur dengan menggunakan metode penelitian kualitatif dan pendekatan multidisiplin. Hasil penelitian menunjukan empat basis kelembagaan gerakan filantropi Islam di Amerika; yaitu masjid, lembaga pendidikan, etnis dan aliran atau madzhab pemikiran. Didapatkan pula fakta hubungan signifikan antara eksistensi lembaga filantropi Islam terhadap kebijakan politik pemerintah terkait isu radikalisme yang melekat pada umat Islam di Amerika.
\end{abstract}

Kata Kunci : Amerika, Filantropi, Islam, Muslim

\section{A. Pendahuluan}

Dimensi sosial ajaran Islam telah dimanifestasikan dalam beberapa tuntunan ibadah; seperti Zakat, Infaq, Sedekah, atau Wakaf. Bahkan dalam beberapa ayat al-Quran, istilah Zakat sering disebutkan bersamaan dengan dengan kata Shalat. Hal ini, menurut alAsqalani yang dikutip oleh Karim ${ }^{1}$, menunjukkan bahwa zakat dan shalat adalah dua ajaran yang menyatu, dengan kata lain, shalat seseorang tidak akan diterima jika belum membayarkan zakatnya.

\footnotetext{
1. Abdul Karim. "Dimensi Sosial dan Spiritual Ibadah Zakat”. Jurnal ZISWAF 2 No.2 (Juni 2015) h.7 http://journal.stainkudus.ac.id/index.php/Ziswaf/article/view/1550 (diakses 3 November 2016)
} 
Dalam beberapa literatur akademis, zakat serta ajaran Islam lain untuk berbagi kepada orang yang membutuhkan, sering dikaitkan dengan istilah fund rising, charitable giving, volunteerism dan philantrophy. Istilah tersebut sama-sama muncul dalam rangka memperkuat kekuatan sosial masyarakat di tingkat akar rumput yang dipandang sebagai bagian dari amal kebajikan individu maupun kelompok.

Bagi seorang muslim, kegiatan filantropi merupakan ekspresi warga negara sekaligus tindakan yang didorong oleh satu keyakinan bahwa orang lain juga memiliki hak untuk hidup sejahtera yang harus diupayakan oleh suatu komunitas ${ }^{2}$. Dengan cara pandang tersebut, aktifitas filantropi memiliki potensi yang besar dalam memperkuat solidaritas kelompok marginal untuk saling memperkuat posisi sosial, ekonomi, maupun politik di sebuah negara.

Umat muslim di negara Amerika merupakan kelompok minoritas, data Pew Research tahun 2007 memperkirakan populasinya antara 2-7 juta jiwa, atau hanya 0,6\%. Namun demikian, umat muslim Amerika tetaplah merupakan kelompok masyarakat yang plural. Potret demografi warganya terdiri dari $65 \%$ adalah immigrant dan sisanya (35\%) terlahir di Amerika. Lebih dari sepertiga (37\%) dari warga yang immigran berasal dari negara- negara Arab. Sekitar $27 \%$ nya berasal dari negara- negara Asia bagian selatan seperti Pakistan, India, Bangladesh, dan Afghanistan. 8\% dari mereka berasal dari negaranegara Eropa, dan sejumlah 6\% berasal dari Afrika. Motif yang melatarbelakangi kedatangan umat Islam ke Amerika pun beragam, beberapa di untuk mendapatkan kesempatan pendidikan (26\%), ekonomi (24\%), alasan keluarga (20\%), dan ada juga karena mengungsi $(20 \%)^{3}$. Dengan keragaman latar belakang tersebut, maka tidak mudah bagi mereka untuk membangun solidaritas umat dan visi bersama untuk meningkatkan posisi tawar sebagai minoritas dan pengembangan filantropi di kalangan umat muslim Amerika.

Penelitian ini akan menguji seperti apa potret perkembangan filantropi Islam di kalangan minoritas muslim di Amerika. Pengkajian akan mengkaitkan peran filantropi Islam terhadap pemberdayaan masyarakat dan solidaritas umat Islam. Penelitian juga

2. Hilman Latief, "Philanthropy and Muslim Citizenship in Post-Suharto Indonesia,". Southeast Asian Studies 5 No. 2 (August 2016) h. 271 https://www.jstage.jst.go.jp/article/seas/5/2/5_269/_article (diakses 5 November 2016)

${ }^{3}$. Pew Forum on Religion and Public Life Team. Muslim Americans: Middle Class and Mostly Mainstream. (USA:Pew Research Center, 2007) h. 15, https://www.pewresearch.org/files/oldassets/pdf/muslim-americans.pdf (diakses 6 Desember 2016) 
membahas peran negara terhadap bentuk dan terhadap praktik filantropi Islam di Amerika Serikat.

Rumusan masalah yang akan dikaji pada penelitian ini dirumuskan dalam pertanyaan-pertanyaan berikut: Bagaimanakah basis kelembagaan Filantropi Islam di Amerika Serikat?, dan Bagaimanakah eksistensi dan peran filantropi Islam di Amerika?

Adapun tujuan dan kegunaan penelitian ini berdasarkan rumusan masalah di atas, penelitian ini memiliki tujuan antara lain: Mengetahui model kelembagaan Filantropi Islam di Amerika Serikat, dan Mengkaji dampak gerakan filantropi terhadap solidaritas dan perekonomian umat Islam di Amerika Serikat.

\section{B. Metode Penelitian}

Studi ini termasuk kedalam kategori penelitian kualitatif dengan pendekatan multidisiplin. Penelitian kualitatif didefinisikan berdasarkan tujuan penelitiannya, yakni memahami beberapa aspek kehidupan sosial. Sebagaimana yang diungkapkan Patton dan Cochran, metode ini pada umumnya akan lebih melibatkan data dalam bentuk kata-kata dibandingkan angka untuk kemudian dianalisis ${ }^{4}$.

Dalam proses pengumpulan data peneliti menggunakan kajian literatur atau pustaka. Dengan demikian, data primer yang dianalisis pada penelitian ini berupa literatur teks berupa buku dan karya sastra yang terkait dengan gerakan filantropi Islam di Amerika. Sementara data sekunder yang digunakan adalah dapat berupa berita dari koran atau majalah, jurnal, serta film seputar Filantropi di Amerika.

Analisis data kualitatif dan pemaparan dalam laporan penelitian melalui beberapa tahap dengan mengadopsi model ${ }^{5}$, antara lain :

1. Pengenalan terhadap data, primer maupun sekuder, melalui review, membaca, atau mendengarkan. Pada tahan ini peneliti akan memperkaya wawasan terhadap objek penelitian, yaitu filantropi Islam di Amerika.

2. Penulisan transkrip informasi penting dari berbagai sumber data, khususnya data yang didapat dari audio visual seperti video atau wawancara.

3. Identifikasi data sesuai dengan klasifikasi tema data yang dibutuhkan dalam analisis dan laporan penelitian.

\footnotetext{
4. Michael Quinn Patton dan Michael Cochran. A Guide to Using Qualitative Research Methodology. (London: Nouria Brikci - Research Officer, 2007) h. 3

5. Lacey, Anne, dan Donna Luff. Trent Focus for Research and Development: An Introduction Qualitative Data Analysis.( Trent Focus, 2001)
} 
4. Eksplorasi untuk mencari keterkaitan antara klasifikasi tema data yang telah didapatkan

5. Selanjutnya adalah pengembangan teori dan penggabungan dengan pengetahuan sebelumnya.

6. Eksaminasi teori dengan data yang telah didapatkan

7. Penulisan laporan.

\section{Hasil dan Pembahasan}

Istilah Filantropi berterkaitan erat dengan istilah kemanusiaan, kepedulian, penyantunan, pemberdayaan, serta peningkatkan hal-hal yang berarti bagi kualitas kehidupan manusia. James Andreoni menjelaskan bahwa motivasi dalam sebuah aktifitas berderma adalah demi generasi umat manusia di masa depan. "Altruism toward others or toward future generations may be a motivator in giving, and gifts are made to maximize a utility function that includes the benefits to others or to society in general." 6

Adapun istilah filantropi Islam sendiri merujuk pada konsep-konsep ajaran Islam yang menyerukan umatnya untuk berbagi dengan orang lain, serta lembaga yang memfasilitasi pembayaran dan pengelolaannya. Konsep itu antara lain mencakup kewajiban membayar zakat, infak, sadaqah, dan wakaf. Meskipun telah menjadi ajaran agama, akan tetapi kesadaran filantropi di tengah umat Islam telah mengalami dinamika konseptual yang panjang.

Di dalam ajaran Islam, aturan berbagi terhadap orang lain dapat dibedakan menjadi dua bagian; pertama bersifat wajib yaitu seperti zakah. Dalam aturan negara, pembayaran tersebut dapat dipadamkan dengan pajak. Adapun kedua lebih bersifat sukarela atau sadaqah. Sadaqah berasal dari kata Sidiq yang berarti percaya, atau mendeklarasikan kepercayaan dengan tindakan. Dua hal tersebut menjadi tolok ukur dan bukti keimanan seorang muslim kepada Allah SWT. ${ }^{7}$ Perintah tersebut termaktub dalam al-Quran surat alBaqarah ayat 261

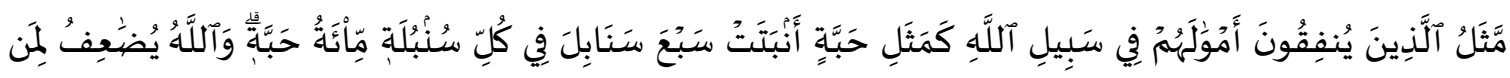

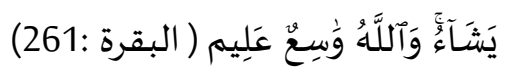

"Perumpaman orang-orang yang menafkahkan hartanya mereka di jalan Allah adalah serupa dengan butir benih yang menumbuhkan tujuh butir, pada setiap butir seratus biji.

\footnotetext{
${ }^{6}$.James Andreoni. Philanthropy. (Wisconsin: University of Wisconsin, 2006) h.1

${ }^{7}$.Fatima Lambarraa dan Gerhard Riener. On the norms of charitable giving in Islam:Two field experiments in Morocco. Journal of Economic Behavior \& Organization (Elsevier) 118 (2015): h.70
} 
Allah (terus-menerus) melipat gandakan bagi siapa yang Dia kehendaki. Dan Allah Maha luas (karuniaNya) Lagi Maha Mengetahui." (Al-Barah: 261)

Tradisi filantropi berbasis keagamaan atau keimanan (faith based) tersebut telah berkembang menjadi sarana solidaritas, ketaatan keagamaan, kohesi sosial, altruisme; dan dapat menjadi cara menciptakan relasi patron klien, interaksi resiprositas, dan juga merupakan ekspresi kebanggaan, kekuatan, dan dominasi. Nomenklatur yang dipakai untuk merepresentasikan lembaga di pihak ketiga ini antara lain adalah: NonGovernmental Organization (NGOs), Non Profit Organizations (NPOs), People's Organization (POs), Private Voluntary Organizations (PVOs), Civil Society Resources Organizations (CSROs), Community Development Association (CDAs), Community Based Organzations (CBOs), Endowed Private Foundation (EPFs), dan Religous Social Institutions $(R S I s)^{8}$.

Amerika adalah salah satu negara paling dermawan di dunia. Amerika menyumbangkan dua kali lipat dari lebih besar dari negara paling dermawan kedua di dunia. Menurut data tahun 2006 yang dipublikasi oleh "Charities Aid Foundation" Amerika menduduki ranking pertama dalam sumbangan sukarela dengan prosentase $1,7 \%$, berturut- turut selanjutnya adalah Inggris $0,7 \%$, Prancis $0,14 \%$, diikuti oleh Afrika Selatan, Singapura, Turki, dan Jerman. ${ }^{9}$

Pada tahun 2015, menurut laporan Giving USA 2016, donasi yang terkumpul dari individu, perumahan, perusahaan, dan yayasan telah mencapai $\$ 373,25$ Milliar. Ini menjadikan tahun 2015 sebagai masa donasi terbesar sepanjang sejarah. Pertumbuhan sumbangan pada tahun 2015 naik sekitar 4,1\% dibanding tahun sebelumnya. Bahkan dua tahun terakhir tersebut merupakan pencapaian tertinggi pertama dan kedua dari pengumbulan dana sukarela di Amerika sepanjang masa. Dari total pencapaian $\$ 373,25$ Milliar pada tahun 2015, sekitar sepertiganya atau \$119,30 Milliar ditujukan bagi institusi keagamaan. Jumlah tersebut sangat besar dan dua tahun tersebut juga mengalami kenaikan yang signifikan, sekitar $2,7 \% .^{10}$

Merujuk pada laporan di atas, sumbangan sukarela yang ditujukan kepada organisasi keagamaan menempati porsi teratas. Jumlah tersebut masih lebih bayak dibanding bidang pendidikan (\$57,48 Milyar), dan pelayanan kemanusiaan $(\$ 45.21$ Milyar). Hal ini menunjukkan bahwa warga negara Amerika memiliki perhatian yang besar

\footnotetext{
${ }^{8}$ Hilman Latief, Politik Filantropi di Indonesia, (Yogyakarta: Penerbit Ombak, 2013), h. 25

${ }^{9}$ Giving USA TM. Giving USA: 2015 Was America's Most-Generous Year Ever. June 13, 2016. https://givingusa.org/giving-usa-2016/ (accessed December 17, 2016)

${ }^{10}$ Giving USA TM, Giving USA: 2015 Was America's... (2016)
} 
terhadap berlangsungnya kegiatan kemanusiaan yang dikelola oleh organisasi berbasis keagamaan. Selain itu, organisasi filantropi keagamaan memiliki peran besar terhadap perubahan sosial di Amerika Serikat.

Filantropi, bagi warga Amerika, merupakan tradisi yang sangat kental dengan masyarakat. Bermacam- macam aktifitas filantropis menjadi tumbuh di semua level sosial masyarakatnya, mulai dari sumbangan dana jutaan dollar, hibah waktu sebagai relawan di gereja lokal, atau sebagai pasukan pemadam kebakaran. Fenomena ini memperkuat adagium warga Amerika yang paradoks. Robert Bellah mengatakan di satu sisi masyarakat sangat individualistik namun di sisi lain sangat idealis menyangkut kehidupan komunitasnya. $^{11}$

Sebuah studi terbaru juga menunjukkan bahwa tingkat religiusitas warga Amerika berbanding lurus terhadap seringnya berderma dalam berbagai bentuknya. Di antara warga Amerika yang mengaku berafiliasi kepada agama tertentu, $65 \%$ sering memberikan amal. Sementara di antara warga Amerika yang tidak berafiliasi kepada satu agama, 56\% mengaku beramal dengan hadiah. Data juga menunjukkan 75\% warga Amerika yang sering menghadiri pelayanan agama juga telah beramal kepada perkumpulannya. Sementara kurang dari separuh dari warga Amerika yang tidak pernah menghadiri kegiatan keagamaan mengaku sering berderma meski bersifat sekuler. ${ }^{12}$ Fakta ini menunjukka bahwa gerakan filantropy berbasis agama atau keimanan (faith-based philanthropy) memberikan kontribusi yang besar dalam perkembangan philanthropy di Amerika. Selain itu, nilai- nilai agama juga menjadi faktor penting dalam mendorong seseorang berbagi dengan orang lain.

\section{Perkembangan Filantropi Berbasis Keagamaan di Amerika}

Organisasi kemanusiaan berbasis keagamaan di Amerika memiliki ciri khas yang membedakan dengan gerakan sekuler. (1) Mereka dimotivasi oleh keyakinan dan mereka memiliki basis konstiten yang lebih luas dari sekadar aspek kemanusiaan. (2) Bagi pemeluknya, Muslim, Yahudi, atau Kristen, mereka memiliki kewajiban merespon kebutuhan kaum miskin dan marjinal. ${ }^{13}$ Meskipun setiap ekspresi setiap keyakinan

\footnotetext{
${ }^{11}$ Robert Bellah, Habits of the Heart, Individualism and commitment in American Life. (Los Angeles: University of California Press, 1985), h.125

12 Alex Daniels, "Religious Americans Give More, New Study Finds." The Chronicle of Philanthropy . 25 November 2013. https://www.philanthropy.com/article/Religious-Americans-Give-More/153973 (diakses December 17, 2016)

${ }^{13}$ Elizabeth Ferris, "Faith-based and secular humanitarian organizations," International Review of the Red Cross 87, no. 858 (June 2005): 312-314, doi:10.1017/s1816383100181366.pdf.
} 
memiliki bentuk yang berbeda dalam tradisi agama yang berbeda, namun spirit keyakinan agama sangat kuat dalam mendorong aksi kemanusiaan.

Schnable berpendapat bahwa agama merupakan faktor yang sangat penting dalam mendorong warga Amerika membantu persoalan internasional dan menentukan melalui organisasi apa bantuan tersebut akan disalurkan. Terdapat alasan untuk mempercayai bahwa pendekatan agama dalam membantu dan membangun yakni menikmati legitimasi yang berkelanjutan dari warga Amerika. Perang Dunia I dan II adalah era keemasan organisasi kemanusiaan berbasis agama seperti Chatolic Relief Service, Lutheran World Relief, dan American Friend Service Committee masih memainkan peran yang sangat signifikan serta menjadi penyandang dana kemanusiaan yang terus meningkat ${ }^{14}$.

Organisasi berbasis keagamaan di Amerika sangat dibutuhkan oleh masyarakatnya, khususnya mereka para gelandangan. Organisasi seperti Gospel Rescue Mission, The Salvation Army, Islamic Relief USA, Helping Hands for Relief and Development menyediakan tempat tinggal, melakukan rehabilitasi bagi pecandu alkohol dan narkotika, serta memberikan pembinaan dengan pelatihan dan lapangan pekerjaan. ${ }^{15}$ Meskipun aktifitas mereka karitatif dan belum menjadi solusi efektif, namun pengaruh mereka sangat besar bagi masyarakat Amerika.

\section{Eksistensi Filantropi Islam di Amerika}

Tradisi filantropi di kalangan Muslim Amerika awalnya berangkat dari individu kepada individu lain. Hal ini bertolak belakang dengan kebiasaan berderma kebanyakan. Data menunjukkan $80 \%$ pendonor muslim adalah individual, padahal peraturan legal tentang penerima pengurangan pajak karena berderma hanya diperuntukkan bagi organisasi. Meskipun akhirnya, khususnya muslim Arab Amerika, mulai menyadari pentingnya mendirikan sebuah institusi. ${ }^{16}$

Sebelum tragedi 9/11, Muslim Amerika sering menyalurkan derma mereka melalui jalur privat atau informal. Seperti Hawala ${ }^{17}$, dan terkadang melalui organisasi amal Islam

\footnotetext{
${ }^{14}$.Schnable Allison. "Religion and Giving for International Faith: Evidence from a Survey of U.S. Church Member." Sociology of Religion 76 (2013): h.75

${ }^{15}$.Ben Grey Bass. "Faith Based Programs and Their Influence for on Homelessness." Fam Community Health 32 (2009): h.31

${ }^{16}$.Susan Ostrander, dan Paul Schervish. "Giving and Getting." dalam Critical Issues in American Philanthropy: Strengthening Theory and Practice, oleh J. Van Til, 67-98. (San Francisco: Jossey-Bass, 1990) h.70

${ }^{17}$.Hawala adalah sistem transfer uang berjejaring tanpa bukti tertuis. Hawala secara bahasa berarti pemindahan atau kepercayaan (trust) yang diamalkan oleh umat islam di seluruh dunia, termasuk di Amerika Serikat. Sistem Hawala diterapkan dengan cara satu pihak membayar lunas kepada orang lain yang kemudian akan dibayarkan dalam jumlah yang sama kepada pihak yang dituju di luar negeri untuk keperluan tertentu.
} 
di Amerika, dan melalui masjid. Sejak 9/11, muslim Amerika enggan untuk berderma melalui fasilitas tersebut karena takut dimata-matai, atau lebih buruknya dilecehkan, ditangkap, atau dituntut karena keterkaitan kegiatan berderma kepada organisasi yang dicurigai oleh pemerintah. Di masa akan datang bukan tidak mungkin mereka akan dianggap sebagai penyokong dana ilegal kepada kelompok teroris. Karena itu, kemampuan dalam menyalurkan zakat secara tepat dapat melindungi muslim Amerika melawan tidak hanya perampasan agama dan pelecehan spiritual tetapi juga dalam jangka yang panjang melindungi reputasi personal dan bisnis, bahkan dari tuduhan kriminal. Salah satu upaya yang dilakukan adalah melalui pembentukan instisui filantropi resmi yang diakui oleh pemerintah. $^{18}$

Pasca tragedi 9/11, pemerintah Amerika memperluas lingkup Undang-Undang, pengetatan administrasi, sanksi kejahatan, dan upaya diplomatik dalam rangka memperuat ketahan nasional. Undang- undang dan program tersebut sangat berpengaruh terhadap kehidupa masyarakat Amerika, khususnya dalah warga muslim Amerika.

Dengan dukungan dari parlemen yang solid, pemerintahan Bush membekukan aset individu atau organisasi dan memasukan dalam daftar orang asing yang diawasi. Orangorang yang aktif dan berkomitmen di dalam daftar tersebut dianggap memiliki resiko tinggi untuk melakukan tindakan terorisme. Keseluruhan daftar tersebut meliputi nama-nama dari 27 orang Arab dan muslim, dikenal dengan Specially Designate Global Terorists (SDGTs) dan Specially Designate National (SDNs) terdapat 12 individu, 15 kelompok, dan tiga NGOs. Tidak hanya itu, aturan Executive Order juga memberikan kuasa kepada pemerintah untuk mengidentifikasi lebih banyak SDGTs dan SDNs dan membekukan aset yang terkait dengan SDGTs dan SDNs yang dicurigai ikut membantu, mensponsori, menyediakan dana, materi atau dukungan teknologi atau hal lain yang membantu terorisme. ${ }^{19}$ Situasi saat itu benar- benar menjadi dilema bagi umat muslim Amerika dalam menunaikan kewajiban membayar zakat ataupun sedekah. Dengan ini berarti gerakan filantropi islam di Amerika mengalami masa surut yang ekstrim.

Adil Najam menunjukkan tumbuhnya kesadaran, di akhir dekade ini, akan pentingnya membuat sebuah institusi seperti masjid, sekolah islam, dan selanjutnya institusi tersebut akan hal ini berakibat pada meningkatnya kegiatan filantropi. Karena itu

Hal ini dilakukan tanpa ada catatan perbankan sehingga tidak dapat dilacak oleh otoritas pemerintah. Lihat (Kamal\&Model, 2004)

${ }^{18}$.Nina J Crimm. "Muslim American Charitable Giving Dilemma: What about Centralized TerrorFree Donor Advised Fund?” Roger Williams University Law Review, 2008: h.375.

${ }^{19}$.Nina J Crimm, (2008) h.377 
kajian tentang kedermawanan yang dilakukan oleh institusi Islam di Amerika penting dilakukan. Pada sisi lain, kondisi sosial politik muslim Amerika juga memunculkan kelompok muslim yang pragmatis dan pluralis. ${ }^{20}$ Kategori ini ditandai dengan cara berfikir yang lebih moderat dan fleksibel dalam menerapkan ajaran agama sesuai konteks sosial politik mereka di Amerika.

Ketika muncul kelompok pragmatis dan pluralis yang memandang perlu mengadopsi norma baru, praktik, dan metode penerapan penunaian kedermawanan yang baru, di sisi lain juga masih ada kelompok yang bertahan dengan cara pandangan tradisionalis, contohnya adalah salafy yang cenderung tekstual. Mereka cederung tekstual dalam membaca dan menafsirkan al-Quran sehingga menjadikan mereka kaku dan tidak fleksibel. Cara pandang tersebut melihat penemuan baru di dunia sebagai bid'ah dan haram. Kelompok ini menjadi tantangan bagi gerakan filantropi Islam di Amerika untuk menuju pada institusionalisasi dan pembuatan regulasi dalam kedermawanan.

Saat ini pemerintah Amerika telah mengubah kebijakan yang tidak ramah terhadap iklim filantropi. Hal ini dilakukan dengan membuat berbagai program edukasi komunitas yang ditujukan kepada masyarakat Muslim Amerika, termasuk gagasan yang bertujuan untuk membantu organisasi kedermawanan. Menyikapi permintaan dari organisasi kedermawanan Muslim Amerika, sejak tahun 2002, departemen keuangan mengeluarkan kebijakan "Anti-Terrorist Financing Guidelines" untuk membantu lembaga donasi yang berbasis di Amerika agar tidak terkait dan tidak dieksploitasi oleh para pelaku tindak terorisme. ${ }^{21}$ Panduan tersebut mengatur secara luas meliputi keuangan dan pokok-pokok program yang bertujuan untuk memperkuat transparasi dan akuntabilitas kedermawanan.

Meskipun mendukung tujuan tersebut namun banyak prantisi filantropi muslim yang memandang bahwa panduan tersebut sangat rumit dan membebani di luar batas kemampuan organisasi kedermawanan.

\section{Basis Filantropi Islam di Amerika}

Kegiatan filantropi Islam di Amerika berkembang melalui aktifitas-aktifitas yang dikelola oleh berbagai basis lembaga amal. Lembaga tersebut didirikan oleh basis-basis yang satu sama lain memiliki ciri khas yang berbeda. Bagian ini akan mengulas basisbasis dari pembentukan organisasi filantropi Islam di Amerika.

${ }^{20}$.Adil Najam, Portrait of a Giving Community. (Cambridge,: Harvard University Press, 2006) h. 45

${ }^{21}$.Office of The Press Secretary. "President Freezes Terrorist's Assets ." 24 September 2001. http://whitehouse.gov/news/releases/2001/09/20010924-4.html; (diakses December 20, 2016). 
a) Filantropi Berbasis Masjid

Meskipun jumlah masjid di Amerika masih sangat sedikit ${ }^{22}$, namun pemanfaatannya oleh warga muslim Amerika sangat komprehensif dibanding sekadar menjadi tempat ibadah saja. Kondisi Islam sebagai minoritas ternyata mendorong kesadaran umatnya untuk memanfaatkan masjid semaksimal mungkin sebagai basis pengembangan dan solidaritas sesama mereka.

Masjid di Amerika bukanlah tempat beriadah saja, akan tetapi mereka juga berperan sebagai pusat kegiatan sosial dan politik. Masjid memainkan peran penting dalam memobilisasi umat Islam untuk memberikan suara pada pemilihan umum. Hal ini berjalan karena $89 \%$ pemimpin masjid percaya bahwa umat Islam seharusnya terlibat dalam proses pemilihan umum. ${ }^{23}$ Bahkan masjid telah dianggap sebagai kekuatan politik nasional baru.

Salah satu kegiatan sosial yang sangat menonjol dari eksistensi masjid di Amerika adalah gerakan filantropi. Nama masjid sering dijadikan sebagai identitas lembaga pengumpul dana dari para dermawan; baik muslim maupun non muslim. Beberapa nama masjid di Amerika yang dijadikan sebagai basis gerakan filantropi antara lain adalah : al Iman Jamee Masjid, al Amin Jamee Masjid, al Ghadir Mosque, al Madinah Masjid, al Masjid Foundation, al Nur Mosque, al Rassoul Mosque, al Faruq Mosque, serta al Alim Jamee.

Esksistensi masjid di Amerika tidak sekadar sebagai fasilitas beribadah, namun lebih dari itu, masjid merupakan simbol keberhasilan dakwah kelompok minoritas. Jumlah masjid di Amerika yang meningkat setiap tahunnya, serta meningkatnya partisipasi umat Islam dalam kegiatan masjid-masjid tersebut menandakan sinyalemen positif atas perkembangan jumlah umat Islam di Amerika. Saat ini sekitar 2 juta umat islam di Amerika terasosiasi dengan masjid-masjid, jumlahnya telah meningkat sekitar $75 \%$ selama lima tahun terakhir. ${ }^{24}$ Dengan perkembangan tersebut, potensi yang dapat dihasilkan dari gerakan filantropi berbasis masjid pun mengalami peningkatan serupa.

Gerakan kedermawanan berbasis masjid merupakan gerakan independen. Namun mereka tetap mengikatkan diri dengan negara. Dalam rangka memfasilitasi penggalangan dana dan mengkapitalisasi keuntungan pemotongan pajak bagi kebanyakan entitas agama, organisasi- organisasi berbasis masjid tersebut biasanya memenuhi persyaratan dari

${ }^{22}$.Data yang dihimpun oleh Salatomatic pada tahun 2015 menunjukkan jumlahnya mencapai 3186 masjid yang tersebar di 53 negara bagian. Jumlah masjid terbanyak berada di negara bagian New York yaitu 343, California, dan Texas 232. Kemudian paling sedikit adalah Vermont yaitu 1 masjid.

${ }^{23}$.Abdus Sattar Ghazali, The Mosques in America: A National Portrait by CAIR. 4 August 2001. http://www.amp.ghazali.net/html/mosques_in_us.html (diakses 12 2016, 22).

${ }^{24}$.Abdus Sattar Ghazali, The Mosques in America (2001), (diakses 12 2016, 22). 
pemerintah untuk dianggap sebagai 501(c)(3) atau tidak bertujuan mencari keuntungan. ${ }^{25}$ Hal ini berarti mereka harus memenuhi ketentuan pemerintah pada status tersebut termasuk dalam hal pengurus organisasi dan akuntabilitas publik.

b) Filantropi berbasis Lembaga Pendidikan

Dunia pendidikan juga menjadi bagian yang tidak terpisahkan dari wacana dan praktik filantropi Islam di Amerika. Proses institusionalisasi gerakan kedermawanan yang semakin kuat di tengah masyarakat muslim Amerika mendorong lembaga pendidikan juga membangun sayap organisasi kegiatannya pada sektor pemberdayaan masyarakat. Dengan demikian, cakupan kegiatan filantropi juga tidak lagi terbatas pada layanan karitatif, tetapai juga terumuskan dalam bentuk pelayanan pendidikan gratis, kesehatan, dan peningkatan ekonomi masyarakat. ${ }^{26}$

Dinamika filantropi islam dengan basis pendidikan beriringan pula dengan konsep masjid yang terpadu dengan layanan pendidikan. Kesadaran ini berangkat dari satu kebutuhan akan adanya lembaga permanen bagi komunitas keyanikan mereka. Lembaga pendidikan berbasis islam dibutuhkan oleh para imigran yang telah mencapai kemapanan ekonomi yang kemudian mencari pengajaran agama dan institusi pendidikan bagi anakanak mereka.

Pendirian fasilitas pendidikan islam dibentuk antara lain seperti Abu Bakar Sidique Islamic Center, Abu Huraira Islamic Center, Academy for Learning Islamic Faith Inc, Al Ajwah Islamic Dawah Learning Center Inc, Al Madina Education Center, Al Noor Islamic Center, Al Huda International Education Center, dan Al Madrasa Al Islamia. Lembagalembaga pendidikan tersebut sebagian besar didanai oleh kegiatan filantropi islam di Amerika.

c) Filantropi Berbasis Etnis

Data Pew Research Center pada tahun 2007 menunjukkan jumlah umat muslim dewasa di Amerika adalah 1,8 juta dan secara keseluruhan adalah berjumlah 2,75 juta dari semua usia yang tinggal di Amerika Serikat. 63\% dari jumlah pada tahun tesebut lahir di luar negeri. 71\% tiba di Amerika setelah tahun 1990. Dari 37\% muslim yang lahir di Amerika, 15\% nya memiliki ayah atau ibu yang lahir di luar negeri. Data ini menunjukkan bahwa mayoritas warga muslim di Amerika adalah pendatang atau imigran dari berbagai negara; Arab, Afrika, Latin, Eropa, atau Asia. ${ }^{27}$

25. Kathleen E. Foley, "The American Mosque: Behind The Controversy.” Policy Brief, 2012: h.6

${ }^{26}$. Hilman Latief, Politik Filantropi, (2013) h. 25

${ }^{27}$.Pew Research Cnter. Muslim Americans. (2007). h.9 
Secara bersama, para imigran dan mereka yang terlahir di Amerika membentuk comunitas agama berbasis ras dan etnis. Tidak ada satu etnis pun pada warga muslim Amerika yang dominan melebihi sepertiga dari total populasinya. Menurut data Pew Research Center, $30 \%$ warga muslim Amerika mengaku kulit putih, 23\% kulit hitam, 21\% Asia, 6\% Hispanic, dan $19 \%$ adalah campuran. Data ini berarti bahwa masyarakat muslim Amerika sangat multikultural. ${ }^{28}$

Salah satu dampak representasi dari etnisitas tersebut adalah munculnya basisbasis komunitas filantropi yang disatukan oleh etnisitas yang sama. Beberapa organisasi kedermawanan berbasis etnis dan ras tersebut antara lain : Albanian Islamic Cultural Center Inc, Afghan American Muslim Outreach, The Alianza Islámica, American Federation of Muslims of Indian Origin,

d) Filantropi Berbasis Aliran Madzhab

Bercermin pada keanekaragaman pemikiran dalam Islam, Pew Research Center menemukan fakta bahwa mayoritas muslim Amerika menerima ajaran tauhid, percaya pada satu Tuhan, percaya bahwa nabi Muhammad adalah nabi terakhir, mempersiapkan hari akhir dan kehidupan setelah kematian. ${ }^{29}$ Namun demikian mereka mempercayai adanya lebih dari satu jalan kebenaran dalam menafsirkan ajaran Islam. Dengan demikian, warga Amerika serikat dianggap sebagai masyarakat yang relijius tetapi tidak dogmatik. ${ }^{30}$

Diantara muslim Amerika terdapat rentang posisi dalam spektrum keberagaman mereka. Pada satu sisi terdapat kelompok Islam yang sangat konservatif pada keyakinan agama dan pandangan hidupnya, namun di sisi lain terdapat kelompok yang sangat liberal. Contohnya dalam hal penggunaan hijab, ada sementara kalangan yang menutup seluruh tubuh, termasuk wajanya. Namun ada kelompok lain yang sekedar menutupkan selembar kain di atas kepala.

Keberagaman itu pula yang menyebabkan munculnya berbagai aliran madzhab dalam keberagaman umat Islam di Amerika, termasuk di negara-negara lain. Menurut data Pew Research Center, 65\% umat islam Amerika mengidentifikasi diri mereka sebagai Sunni. Kelompok ini adalah mayoritas di Amerika, walaupun dalam kasus- kasus tertentu penyikapan di internal mereka pun berbeda. Sementara $11 \%$ sisanya berafiliasi pada

\footnotetext{
${ }^{28}$.Pew Research Cnter. Muslim Americans, (2007). h.11

${ }^{29}$.Pew Research Cnter. Muslim Americans, (2007). h.13

${ }^{30}$ Kathleen E Foley, The American Mosque, (2012): h.10
} 
madzhab Shiah, sementara sisanya $24 \%$ mengaku tidak berafiliasi pada aliran madzhab tertentu. $^{31}$

Basis-basis aliran madzhab tersebut memunculkan berdirinya organisasi amal filantropi yang diafiliasikan kepada aliran masing- masing, seperti Sunni, Syiah, ataupun Ahmadiyah. Beberapa organisasi tersebut adalah : Islamic Society of North America (beraliran Sunni), The North American Shia Ithna-Asheri Muslim Communities (beralilran Syiah), Ahmadiyya Muslim Community, dan Zaituna Institute (Salafy).

\section{Penutup}

Amerika sebagai negara paling dermawan merupakan negara yang sangat kompatibel terhadap perkembangan filantropi Islam. Meskipun menghadapi tantangan pada saat tragedi 9/11, namun gerakan filantropi Islam tetap tumbuh dan bertaransformasi dalam bentuk lembaga yang jauh lebih progresif dan profesional. Dari awalnya bersifat individu dan ditujukan kepada individu, gerakan filantropi Islam Amerika kini telah mengalami institusionalisasi dengan berbagai basis antara lain, masjid, pendidikan, etnis, dan aliran madzhab dalam memahami Islam.

Gerakan filantropi Islam mulai menyita perhatian akademis dan pakar filantropi. Dimana mulanya, perhatian terhadap gerakan filantropi berbasis keyakinan (Faith Based Organization) belum tersentuh oleh kajian para akademisi. Dengan demikian, masa depan filantropi Islam di Amerika, baik secara kelembagaan maupun secara akademis memiliki prospek semakin cerah dalam berkontribusi kepada masyarakat.

\section{E. Daftar Pustaka}

Abu Bakar Asshidiq Islamic Center. Islamic Study (Sisters). 2016. http://masjidabubakar.org/islamic-study-sisters (diakses December 22, 2016).

Afghan American Muslim Outreach (AAMO) . About AAMO . 2016. https://aamousa.com/about-us/ (diakses December 20, 2016).

Ahmadiyya Muslim Community. Abotu Ahmadiyya Muslim Community. 2 April 2009. http://www.ahmadiyya.us/about-ahmadiyya-muslim-community

(diakses December 23, 2016).

Al Huda Online. What is Al Huda Online About? 2016. http://www.alhudaus.com/about.asp (diakses December 22, 2016).

${ }^{31}$ Pew Research Cnter. Muslim Americans, (2007). h.20 
Al Madrasa AL Islamiya. Abotu Al Madrasa AL Islamiya. 2016. http://www.almadrasanyc.com/about-c1x1t (diakses December 22, 2016).

Albanian Islamic Cultural Center. Albanian Islamic Cultural Center. 2015. http://www.aiccny.com/home/?page_id=2 (diakses December 22, 2016).

Alianza Islamica. A BRIEF HISTORY OF ALIANZA ISLAMICA: THE OFFICIAL STORY. 21 December 2016. http://latinomuslim.com/brief-history-alianza-islamica-officialstory (diakses December 22, 2016).

American Federation of Muslim of Indian Origin. Abotu AFMI. 2014. http://www.afmi.org/\# (diakses December 22, 2016).

Andreoni, James. Philanthropy. Wisconsin: University of Wisconsin, 2006, 1-73.

Bass, Ben Grey. "Faith Based Programs and Their Influence for on Homelessness." Fam Community Health 32 (2009): 314-319.

Ba-Yunus, Ilyas, dan Kassim Kone. Muslims in the United States. London: Greenwood Press, 2006.

Bellah, Robert. Habits of the Heart, Individualism and commitment in American Life. Los Angeles: University of California Press, 1985.

Bremer, Jennifer. "Islamic Philantrophy; Reviving Traditional Form for Building Social Justice." CSID Fifth Annual Conference. Washinton: Center for the Study of Islam dan Democracy, 2004. 3-4.

Chaves, Mark. "Religious Congregations and welfare reform: Assesing the potential." Dalam Can Charitable Choice Work?, oleh Andrew Walsh, 121-139. Hartford: Trinity College, 2001.

Crimm, Nina J. "Muslim American Charitable Giving Dilemma: What about Centralized Terror-Free Donor Advised Fund?” Roger Williams University Law Review, 2008: $375-482$.

Daniels, Alex. "Religious Americans Give More, New Study Finds." The Chronicle of $\begin{array}{llll}\text { Philanthropy } & \text {. } & 25 & \text { November }\end{array}$ https://www.philanthropy.com/article/Religious-Americans-Give-More/153973 (diakses December 17, 2016).

Ferris, Elizabeth. "Faith-Based and Secular Humanitarian Organization." International Review of The Red Cross, 2005: 311-325.

Foley, Kathleen E. “The American Mosque: Behind The Controversy.” Policy Brief, 2012: $1-22$.

Fulton, Katherine, dan Andrew Blau. "Cultivating Change in Philanthropy." Monitor Institute. $2005 . \quad \mathrm{http} / /$ www.monitorinstitute.com/downloads/what-we- 
think/looking-out-for-the-future/Cultivating_Change_in_Philanthropy.pdf (diakses December 15, 2016).

Ghazali, Abdus Sattar. The Mosques in America: A National Portrait by CAIR. 4 August 2001. http://www.amp.ghazali.net/html/mosques_in_us.html (diakses 12 2016, 22).

Giving USA TM. Giving USA: 2015 Was America's Most-Generous Year Ever. 13 June 2016. https://givingusa.org/giving-usa-2016/ (diakses December 17, 2016).

Huda, Qomar-ul. The Diversity of Muslims in the United States; view as Americans. Washinton: United States Institute of Peace, 2006.

Karim, Abdul. "Dimensi Sosial dan Spiritual Ibadah Zakat." Jurnal ZISWAF (Prodi Zakat dan Wakaf STAIN Kudus) 2 (Juni 2015): 2.

Khan, Sabithulla. "Faith-Based Charitable Giving and Its Impact on Notions of "Community": The Case of American Muslim NGOs." Qualitative Sociology Review XI (2015): 138-160.

Lacey, Anne, dan Donna Luff. Trent Focus for Research and Development: An Introduction Qualitative Data Analysis. Trent Focus, 2001.

Lambarraa, Fatima, dan Gerhard Riener. "On the norms of charitable giving in Islam:Two field experiments in Morocco." Journal of Economic Behavior \& Organization (Elsevier) 118 (2015): 69-84.

Latief, Hilman. "Philanthropy and "Muslim Citizenship" in Post-Suharto Indonesia." Southeast Asian Studies (Center for Southeast Asian Studies, Kyoto University) 5 (August 2016): 269-286.

—. Politik Filantropi di Indonesia. Yogyakarta: Penerbit Ombak, 2013.

—. Politik Filantropi Islam di Indonesia. Yogyakarta: Penerbit Ombak, 2013.

Office of The Press Secretary. "President Freezes Terrorist's Assets ." 24 September 2001. http://whitehouse.gov/news/releases/2001/09/20010924-4.html; (diakses December 20, 2016).

Patton, Michael Quinn, dan Michael Cochran. A Guide to Using Qualitative Research Methodology. London: Nouria Brikci - Research Officer, 2007.

Pew Research Cnter. Muslim Americans. USA: Pew Research Center, 2007.

Rais, Amien. Tauhid Sosial: Formula Menggempur Kesenjangan . Yogyakarta: ATF Press, 1998.

Salamon, Lester. The State of Nonprofit America. Washinton: Brookings Institution Press, 2002. 
Schnable, Allison. "Religion and Giving for International Faith: Evidence from a Survey of U.S. Church Member.” Sociology of Religion 76 (2013): 72-94.

Swanson, Abbie Fentress. Park 51 Opens Renovated Space with Photo Exhibit on NYC $\begin{array}{lllll}\text { Immigrant } \quad \text { Children } & 21 & \text { September } & 2011 .\end{array}$ http://www.wnyc.org/articles/features/2011/sep/21/park-51-gallery-show/ (diakses October 3, 2011).

The Academi for Learning Islam. Course Archives. 2016. https://www.academyofislam.com/courses/ (diakses December 22, 2016).

The Editors of Encyclopædia Britannica. Philanthropy. 27 September 2013. https://www.britannica.com/topic/philanthropy (diakses December 14, 2016).

The Islamic Society of North America. About ISNA. 2016. http://www.isna.net/about-isna/ (diakses December 22, 2016).

The North American Shia Ithna-Asheri Muslim Communities . About NASIMCO. 2006. http://www.nasimco.org/About-NASIMCO/about-nasimco.html (diakses December 22, 2016). 